\title{
The Prognostic Significance Of Pretreatment Albumin/alkaline Phosphatase Ratio In Patients With Stage IB-IIA Cervical Cancer
}

This article was published in the following Dove Press journal: OncoTargets and Therapy

\author{
Can Zhang ${ }^{1, *}$ \\ Yong Li $\mathbb{D}^{1, *}$ \\ Rui Ji ${ }^{1}$ \\ Weiling Zhang' \\ Chenfei Zhang ${ }^{2}$ \\ Youli Dan ${ }^{3}$ \\ Hongyan Qian (iD) \\ Aiqin $\mathrm{He}^{\mathrm{l}}$ \\ 'Department of Gynecology Oncology, \\ Tumor Hospital Affiliated to Nantong \\ University, Nantong, People's Republic of \\ China; ${ }^{2}$ Department of Medical \\ Oncology, Tumor Hospital Affiliated to \\ Nantong University, Nantong, People's \\ Republic of China; ${ }^{3}$ Department of \\ Oncology, Medical College of Nantong \\ University, Nantong, People's Republic of \\ China; ${ }^{4}$ Cancer Research Centre \\ Nantong, Tumor Hospital Affiliated to \\ Nantong University, Nantong, People's \\ Republic of China
}

*These authors contributed equally to this work

Correspondence: Aiqin $\mathrm{He}$ Department of Gynecology Oncology, Tumor Hospital Affiliated to Nantong University, 30 Tongyang North Road, Nantong 226300, People's Republic of China

Tel +86 I39 62931600

Fax +86 5I3 867I 2287

Email haq0II8@I63.com

Hongyan Qian

Cancer Research Centre Nantong, Tumor Hospital Affiliated to Nantong University, 30 Tongyang North Road, Nantong 226300, People's Republic of China

$\mathrm{Tel} / \mathrm{Fax}+86513867 \mathrm{I} 2287$

Email qhy672041647@I63.com
Background: Pretreatment albumin/alkaline phosphatase ratio (AAPR) has been discussed about its prognostic value in several malignancies, whereas its role in cervical cancer remains unclear. In this study, we attempt to explore the prognostic significance of the AAPR in stage IB-IIA cervical cancer patients who underwent a radical hysterectomy.

Patients and methods: A total of 230 cervical cancer patients were enrolled in this retrospective study. The threshold value of AAPR was determined by receiver operating characteristic (ROC) curve. Kaplan-Meier survival analysis and multivariate analysis were performed to identify independent prognostic predictors of disease-free survival (DFS) and overall survival (OS).

Results: The optimal cut-off value of the preoperative AAPR was 0.68. Patients with AAPR $<0.68$ showed obviously inferior OS and DFS than those with AAPR $>0.68$ according to Kaplan-Meier curves (DFS: $\mathrm{P}=0.011$; OS: $\mathrm{P}=0.017$ ). In multivariate analysis, the preoperative AAPR showed to be an independent predictive factor for disease-free survival (DFS: $\mathrm{P}=0.015)$ and overall survival (OS: $\mathrm{P}=0.019)$. Moreover, subgroup analysis revealed that the lower AAPR was correlated with worse prognosis in patients with histologic grade I-II; but in those with histologic grade III, there was no significant difference between the two groups.

Conclusion: Preoperative AAPR was a potentially valuable prognostic index in stage IBIIA cervical cancer patients. Further prospective studies are required to validate its prognostic value.

Keywords: albumin-to-alkaline phosphatase ratio, uterine cervical neoplasms, prognosis, survival analysis

\section{Introduction}

Cervical carcinoma is the most common cancer of the female genital tract and the fourth primary cause of malignancy-related deaths among women, giving rise to approximately 527600 new cases and 265700 deaths each year worldwide, especially in low-and middle-income countries. ${ }^{1}$ At present, radical hysterectomy followed by chemotherapy or chemoradiation has been widely accepted as effective treatments in patients with IB-IIA stage cervical cancer. ${ }^{2,3}$ Nevertheless, once disease recurrence occurs, the prognosis is relatively poor because of limited clinical therapies. ${ }^{4-6}$

Established prognostic factors associated with recurrence, progression, or death include parametrial involvement (PMI), lymph node metastasis (LNM), and 
positive surgical margins, which require confirmation of postoperative pathology. ${ }^{7}$ A simpler and more economic index to predict the clinical outcomes for early-stage cervical cancer patients effectively is required.

At the moment, certain laboratory indexes have been validated as prognostic indicators in cervical cancer, including $\mathrm{C}$ - reactive protein/albumin ratio (CAR), neutrophil-tolymphocyte ratio (NLR) and prognostic nutritional index (PNI). ${ }^{8-10}$ The albumin (ALB) to alkaline phosphatase (ALP) ratio (AAPR) was first revealed as a prognostic index for hepatocellular carcinoma in 2015 as another available indicator for assessing the nutritional status, inflammation level, and immune response. ${ }^{11}$ Subsequently, it has been reported as a novel prognostic factor in different malignant carcinomas, including nasopharyngeal carcinoma, pancreatic ductal adenocarcinoma, breast cancer, lung cancer, and cholangiocarcinoma. ${ }^{12-17}$

However, the pretreatment level of AAPR and their prognostic role in cervical cancer have not ever been evaluated. Hence, we retrospectively studied the prognostic significance of AAPR in cervical cancer patients with stage IB-IIA disease, followed by the correlation of AAPR with other clinicopathological features.

\section{Methods}

\section{Patients}

We retrospectively reviewed patients histologically confirmed cervical cell carcinoma (stage IB-IIA) at Tumor Hospital Affiliated to Nantong University from January 2008 to June 2014. Patients were treated with radical hysterectomy plus pelvic lymphadenectomy without neoadjuvant chemotherapy or preoperative radiotherapy. Adjuvant therapy after surgery was considered based on pathological risk factors. The exclusion criteria were listed in the following: 1 . receiving conization before radical hysterectomy; 2 . with incomplete pathological information; 3. with previous or coexisting cancers; 4. without available follow-up data; 5 . with diseases that could affect ALB or ALP level, such us liver disease, bone disease and active infectious disease. Our study was approved by the Ethics Committee of Tumor Hospital Affiliated to Nantong University and were in accordance with the 1964 Helsinki Declaration and its amendments. Informed consent was not required as the study was based on retrospective anonymous patient data and was not involved with patient intervention or the use of human tissue samples.

\section{Data Collection}

Baseline clinicopathological features and laboratory assessments were intensively reviewed and obtained from the hospital database. We recorded patient age, menstruation, FIGO (International Federation of Gynecology and Obstetrics) stage, tumor size, treatment regimens, and histopathological parameters for analysis. Besides, ALB and ALP levels were retrieved within seven days before radical surgery. The preoperative AAPR was calculated as follows: $\mathrm{AAPR}=$ pretreatment serum albumin level $(\mathrm{g} / \mathrm{L}) /$ alkaline phosphatase level (U/L).

Deadline for follow-up is July 9, 2019. We defined overall survival (OS) time as the period from the initial treatment to death due to cervical carcinoma or to the last follow-up date if the patient remained alive. The diseasefree survival (DFS) time was defined as the interval from the initial treatment to relapse or death, or the last followup visit if no recurrence or death occurred.

\section{Statistical Analysis}

Receiver operating curve (ROC) was utilized to evaluate the diagnostic performance of ALP, ALB and AAPR, and the largest Youden index (sensitivity + specificity-1) was selected as the optimal cut-off point. Independent-samples $t$-test or Mann-Whitney $U$-test was used to compare the difference of continuous variables between groups, and Chi-squared test or Fisher's exact test was employed for categorical variables. Survival data, including OS and DFS among the classification groups, were calculated using the Kaplan-Meier method and were compared using the log rank test. Univariate and multivariate Cox proportional hazards regression models were performed to identify the independent prognostic factors. Results were reported as hazard ratio (HR) and 95\% confidence interval (CI). A two-sided $\mathrm{P}<0.05$ was considered to indicate statistical significance. All statistical analysis were obtained by using IBM SPSS software (Statistical Package for the Social Sciences; Version 25.0).

\section{Results}

\section{Patient Clinic Characteristics}

The study evaluated 484 patients (stage IB-IIA) who underwent a radical hysterectomy, and 230 patients were included finally (Figure 1).

The clinicopathological features of the patients were analyzed and shown in Table 1 . The median age of the cohort at the time of diagnosis was 55 years (range: 29-79 
Patients dignosed with IB-IIA cervical cancer who underwent radical hysterectomy from January 2008 to June $2014(n=484)$

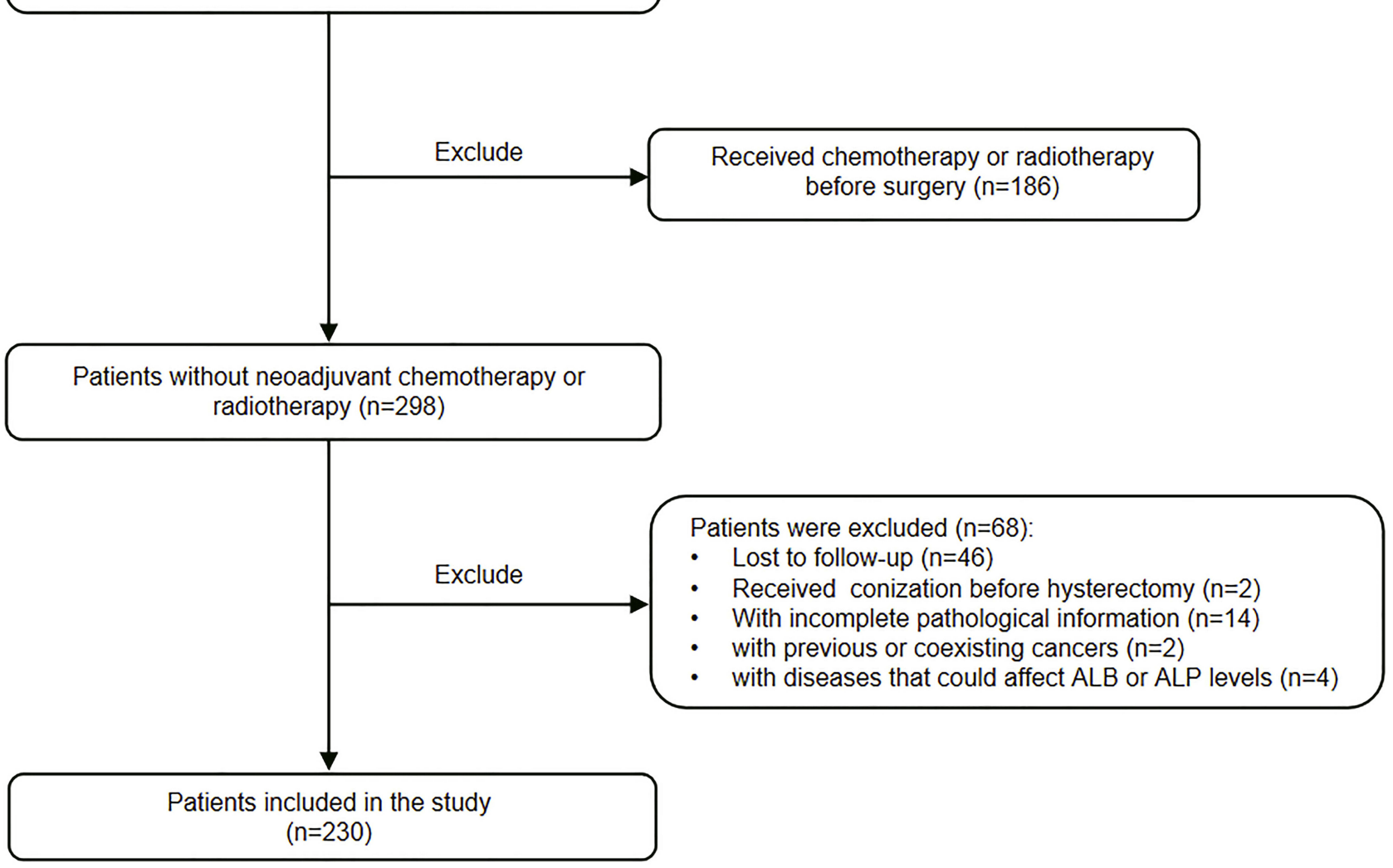

Figure I Flow chart of patient selection.

Abbreviations: ALB, albumin; ALP, alkaline phosphatase.

years), and their median follow-up time was 81 months (range: $12-137$ months). According to FIGO staging, there were 201 patients $(87.4 \%)$ in IB and 29 patients (12.6\%) in IIA.

\section{Relationship Between AAPR And Patient Characteristics}

We used ROC curve analysis to determine the predictive significance of pretreatment values of ALB, ALP, and AAPR. Using OS as an endpoint, the area under the ROC curve was 0.631 (95\% CI, 0.516-0.746; $\mathrm{P}=0.025$ ) for ALB, $0.616(95 \% \mathrm{CI}, 0.501-0.732 ; \mathrm{P}=0.046)$ for ALP and 0.654 (95\% CI, 0.539-0.769; $\mathrm{P}=0.008)$ for AAPR, and the sensitivities (specificities) were $63.9 \%(60.7 \%), 75 \%$ (54.5\%), 43.1\% (85.7\%), respectively (Figure 2). The respective optimal cutoff value for ALB, ALP, and AAPR were $45.5,73.5$, and 0.68 , corresponding to maximum joint sensitivity and specificity. Then, 141 patients
(61.3\%) with AAPR $<0.68$ and 89 patients (38.7\%) with ALP $\geq 0.68$ were classified into low and high AAPR groups. The relationship between the preoperative AAPR and clinicopathological parameters of cervical cancer patients is shown in Table 1. According to the analysis, significant differences between the low and high preoperative AAPR groups were identified for age $(\mathrm{P}<0.001)$, menstruation ( $\mathrm{P}<0.001)$, depth of invasion $(\mathrm{P}=0.045)$, and ALP level $(\mathrm{P}<0.001)$. However, there was no significant difference between FIGO stage $(\mathrm{P}=0.189)$, pathological type $(\mathrm{P}=0.054)$, tumor size $(\mathrm{P}=0.313)$, histologic grade $(\mathrm{P}=0.176)$, lymphovascular space invasion $(\mathrm{P}=0.875)$, LNM $(\mathrm{P}=0.748)$, vaginal invasion $(\mathrm{P}=0.770)$, adjuvant therapy $(\mathrm{P}=0.419)$ and ALB level $(\mathrm{P}=0.141)$.

\section{Survival Analysis}

The 5-year overall survival (OS) rate and disease-free survival (DFS) rate in the AAPR-low group were significantly lower than those in the AAPR-high group (OS: 
Table I The Relationship Between The Preoperative AAPR And Clinicopathological Variables

\begin{tabular}{|c|c|c|c|c|}
\hline Variables & Total $(n=230)$ & AAPR $<0.68$ & AAPR $\geq 0.68$ & P-value \\
\hline $\begin{array}{l}\text { Age } \\
\leq 55 \text { years } \\
>55 \text { years }\end{array}$ & $\begin{array}{l}\text { II } 5(50 \%) \\
\text { II } 5(50 \%)\end{array}$ & $\begin{array}{l}52(45.2 \%) \\
89(77.4 \%)\end{array}$ & $\begin{array}{l}63(54.8 \%) \\
26(22.6 \%)\end{array}$ & $<0.00 I^{*}$ \\
\hline $\begin{array}{l}\text { menopause } \\
\text { No } \\
\text { Yes }\end{array}$ & $\begin{array}{l}98(42.6 \%) \\
132(57.4 \%)\end{array}$ & $\begin{array}{l}4 \mathrm{I}(4 \mathrm{I} .8 \%) \\
100(75.8 \%)\end{array}$ & $\begin{array}{l}57(58.2 \%) \\
32(24.2 \%)\end{array}$ & $<0.00 I^{*}$ \\
\hline $\begin{array}{l}\text { FIGO stage } \\
\text { IB } \\
\text { IIA }\end{array}$ & $\begin{array}{l}20 \mathrm{I}(87.4 \%) \\
29(12.6 \%)\end{array}$ & $\begin{array}{l}120(59.7 \%) \\
2 \mid(72.4 \%)\end{array}$ & $\begin{array}{l}81(40.3 \%) \\
8(27.6 \%)\end{array}$ & 0.189 \\
\hline $\begin{array}{l}\text { Pathological type } \\
\text { SCC } \\
\text { No-SCC }\end{array}$ & $\begin{array}{l}192(83.5 \%) \\
38(16.5 \%)\end{array}$ & $\begin{array}{l}123(64.1 \%) \\
18(47.4 \%)\end{array}$ & $\begin{array}{l}69(35.9 \%) \\
20(52.6 \%)\end{array}$ & 0.054 \\
\hline $\begin{array}{l}\text { Tumor Size } \\
\leq 2 \mathrm{~cm} \\
>2 \mathrm{~cm}\end{array}$ & $\begin{array}{l}\text { II } 3 \text { (49.1\%) } \\
\text { II (50.9\%) }\end{array}$ & $\begin{array}{l}73(64.6 \%) \\
68(58.1 \%)\end{array}$ & $\begin{array}{l}40 \text { (35.4\%) } \\
49 \text { (4I.9\%) }\end{array}$ & 0.313 \\
\hline $\begin{array}{l}\text { Histologic grade } \\
\text { I-II } \\
\text { III }\end{array}$ & $\begin{array}{l}124(53.9 \%) \\
106(46.1 \%)\end{array}$ & $\begin{array}{l}81(65.3 \%) \\
60(56.6 \%)\end{array}$ & $\begin{array}{l}43 \text { (34.7\%) } \\
46 \text { (43.4\%) }\end{array}$ & 0.176 \\
\hline $\begin{array}{l}\text { Depth of invasion } \\
<2 / 3 \\
\geq 2 / 3\end{array}$ & $\begin{array}{l}172(74.8 \%) \\
58(25.2 \%)\end{array}$ & $\begin{array}{l}99(57.6 \%) \\
42(72.4 \%)\end{array}$ & $\begin{array}{l}73(42.4 \%) \\
16(27.6 \%)\end{array}$ & $0.045^{*}$ \\
\hline $\begin{array}{l}\text { LVSI } \\
\text { No } \\
\text { Yes }\end{array}$ & $\begin{array}{l}200(87.0 \%) \\
30(13.0 \%)\end{array}$ & $\begin{array}{l}123(61.5 \%) \\
18(60 \%)\end{array}$ & $\begin{array}{l}77 \text { (38.5\%) } \\
12(40 \%)\end{array}$ & 0.875 \\
\hline $\begin{array}{l}\text { LNM } \\
\text { No } \\
\text { Yes }\end{array}$ & $\begin{array}{l}196(85.2 \%) \\
34(14.8 \%)\end{array}$ & $\begin{array}{l}|2|(61.7 \%) \\
20(58.8 \%)\end{array}$ & $\begin{array}{l}75(38.3 \%) \\
14(41.2 \%)\end{array}$ & 0.748 \\
\hline $\begin{array}{l}\text { Vaginal invasion } \\
\text { No } \\
\text { Yes }\end{array}$ & $\begin{array}{l}218(94.8 \%) \\
12(5.2 \%)\end{array}$ & $\begin{array}{l}133(61.0 \%) \\
8(66.7 \%)\end{array}$ & $\begin{array}{l}85(39.0 \%) \\
4(33.3 \%)\end{array}$ & 0.770 \\
\hline $\begin{array}{l}\text { Adjuvant therapy } \\
\text { No } \\
\text { Chemoradiotherapy } \\
\text { Chemotherapy } \\
\text { Radiotherapy }\end{array}$ & $\begin{array}{l}84(36.5 \%) \\
57(24.8 \%) \\
84(36.5 \%) \\
5(2.2 \%)\end{array}$ & $\begin{array}{l}56(66.7 \%) \\
31(54.4 \%) \\
50(59.5 \%) \\
4(80 \%)\end{array}$ & $\begin{array}{l}28(33.3 \%) \\
26(45.6 \%) \\
34(40.5 \%) \\
I(20 \%)\end{array}$ & 0.419 \\
\hline $\begin{array}{l}\operatorname{ALB}(g / L) \\
\operatorname{ALP}(\cup / L)\end{array}$ & $\begin{array}{l}46.3 \pm 4.2 \\
81.3 \pm 57.0\end{array}$ & $\begin{array}{l}46.0 \pm 4.4 \\
97.8 \pm 67.3\end{array}$ & $\begin{array}{l}46.8 \pm 4.0 \\
55.1 \pm 10.5\end{array}$ & $\begin{array}{l}0.141 \\
<0.00 I^{*}\end{array}$ \\
\hline
\end{tabular}

Notes: Independent-Samples T test or Mann-Whitney U-test was employed for continuous variables. Chi-squared test or Fisher's exact test was employed for categorical variables. ${ }^{*} \mathrm{P}<0.05$.

Abbreviations: AAPR, albumin/alkaline phosphatase ratio; FIGO, International Federation of Gynecology and Obstetrics; SCC, squamous cell carcinoma; LVSI, lymphovascular space invasion; LNM, lymph node metastasis; ALB, albumin; ALP, alkaline phosphatase.

83.0\% VS 95.5\%, $\mathrm{P}=0.005$; DFS: $80.1 \%$ VS $93.3 \%$, $\mathrm{P}=0.006$ ). The Kaplan-Meier survival curves demonstrated that AAPR $<0.68$ was significantly associated with worse OS and DFS (Figure 3).
Univariate and multivariate analyses were performed to identify the prominently independent prognostic factors in cervical cancer (Table 2). The results showed that AAPR was indicated as an independent prognostic index for OS (HR, 
A

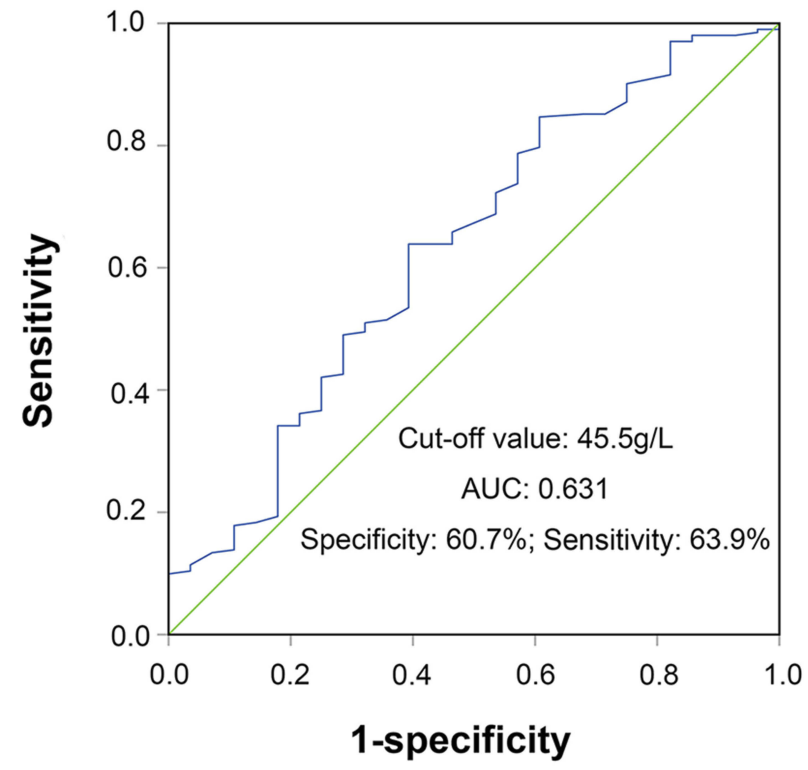

B

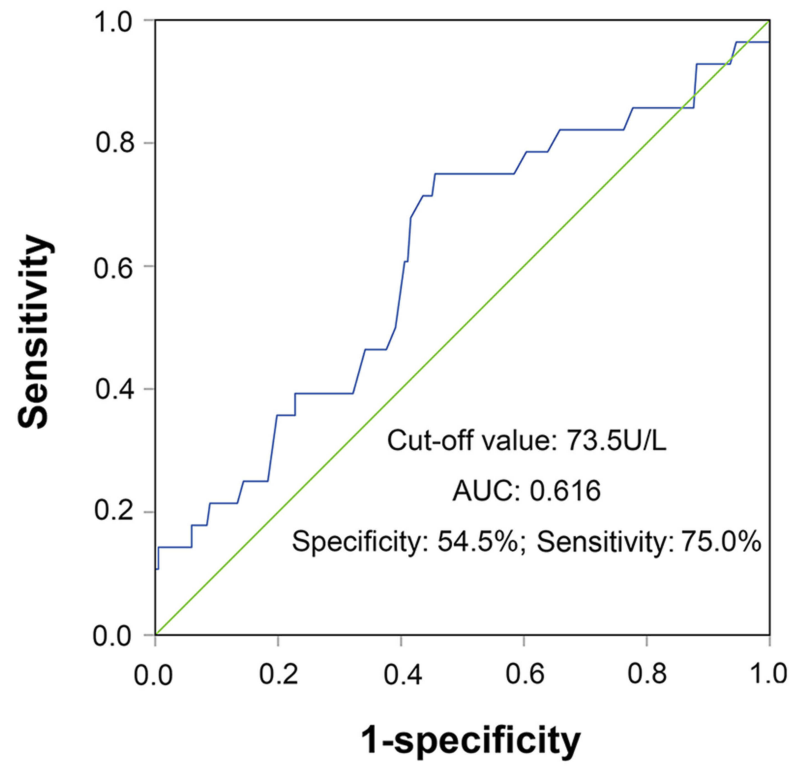

C

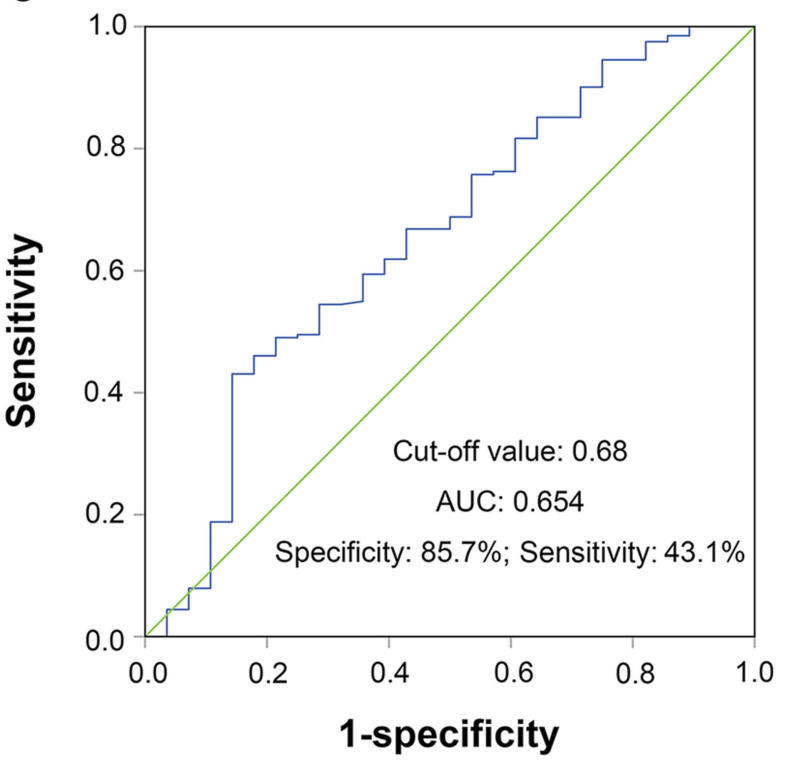

Figure 2 Receiver operating characteristics curve analysis based on ALB (A), ALP (B), and AAPR (C) for overall survival.

Abbreviations: ALB, albumin; ALP, alkaline phosphatase; AAPR, albumin/alkaline phosphatase ratio.

\section{$0.331 ; 95 \% \mathrm{CI}, 0.135-0.809 ; \mathrm{P}=0.015)$ and DFS (HR, 0.387;} 95\% CI, 0.176-0.853; $\mathrm{P}=0.019)$. Additionally, other factors, including FIGO stage, pathological type, and adjuvant therapy, were also determined to be independent prognostic predictors for OS and DFS in multivariate analysis.

Moreover, subgroup analysis suggested that AAPR $<0.68$ was significantly related to inferior prognosis in patients with histologic grade I-II; however, in patients with histologic grade III, there was no difference between the two groups (Figure 4).

\section{Discussion}

In this retrospective study, we demonstrated that AAPR was an independent predictor in cervical cancer patients receiving radical hysterectomy. Our results showed that AAPR levels under 0.68 were associated with poor OS and DFS. To our knowledge, this is the first study analyzing the association of AAPR with cervical cancer.

ALB, as a stable and flexible serum protein, is generally considered a biomarker for liver function and nutritional 
A

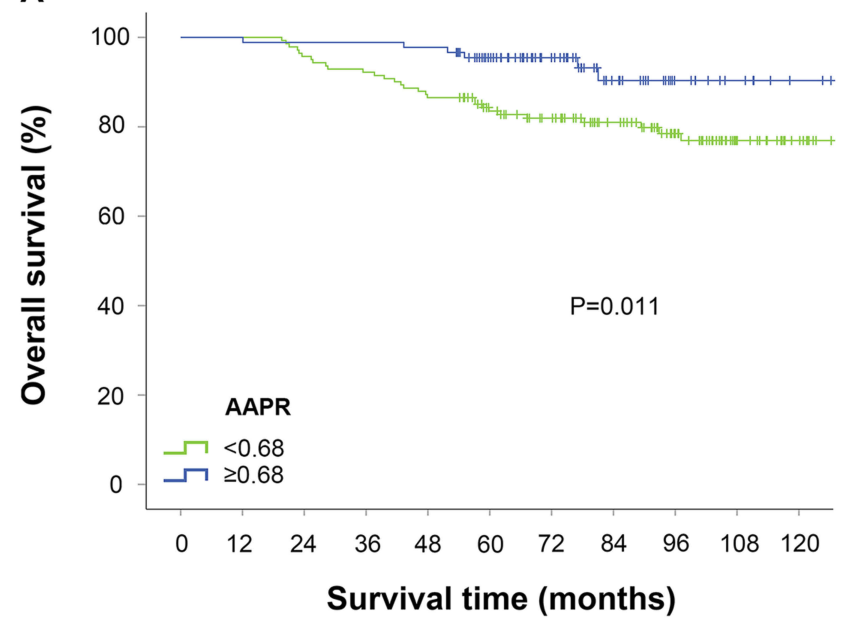

B

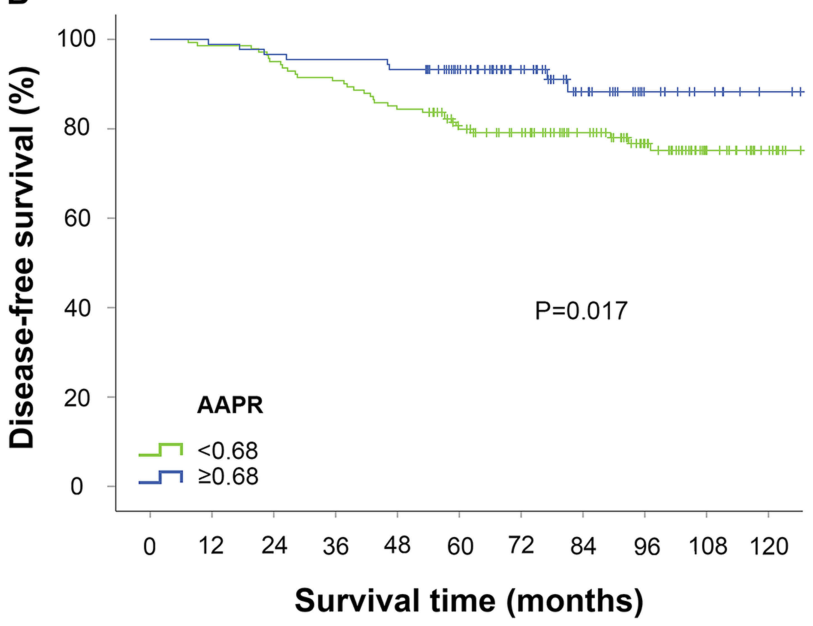

Figure 3 Kaplan-Meier curves stratified according to AAPR value for the overall survival (A) and disease-free survival (B). The P-values were determined by the log rank test. Abbreviation: AAPR, albumin/alkaline phosphatase ratio.

status. Moreover, it was reported with the ability to stabilize cell growth and DNA proliferation, exert antioxidant effects against carcinogens and modulate immune reaction, which plays a vital role in tumorigenesis. ${ }^{18-20}$ Therefore, a low level of ALB might correlate with insufficient hepatic function, decreased immune capability, and inadequate anticancer response. Several previous reports have shown the prognostic value of ALB in malignant tumors, including breast cancer, kidney cancer, lung cancer and colorectal cancer. ${ }^{15,21-23}$ ALP is known as a phosphate monoester hydrolase and mainly concentrate in the liver, bone, bile duct, kidney, and placenta. ${ }^{24,25}$ It is commonly recognized to have high diagnosis specificity in bone metastasis and has been reported in certain bony metastasis malignancies. ${ }^{26-28}$ Additionally, ALP was found to influence inflammation through regulation of purinergic signaling and induce an inhibitory immune response. ${ }^{29}$ Besides, ALP can be generated and released into the blood directly by tumor cells and regulates tumor growth. ${ }^{30}$ Therefore, evaluation of ALP might manifest as a heavy tumor burden and have prognostic value in cancer patients. ${ }^{31,32}$

As reported, the majority of cervical cancer cases are associated with persistent human papillomavirus (HPV) infections and chronic inflammation it induced. ${ }^{33,34}$ The weakened systematic and local immune response plays an important role in the process. ${ }^{35}$ Furthermore, approximately $62-88 \%$ of gynecological cancer patients are prone to experience malnutrition. ${ }^{36}$ Prior studies have shown that nutrient deficiency and systematic inflammatory response might play a critical role in the pathogenesis and progression of human carcinomas and were correlated with inferior prognosis in patients undergoing resection for solid tumors. ${ }^{8,37-39}$ Zheng et al have demonstrated that ALB is an independent prognostic indicator in early operable cervical cancer. ${ }^{40}$ Moreover, a recent published article found that high levels of ALP could influence tumorigenesis and predict outcomes in cervical cancer patients. ${ }^{41}$ In our present study, the AUC of AAPR was similar to that of ALB and ALP. However, AAPR has several advantages in cervical cancer patients compared with the other two indices. On one hand, both ALB and ALP can be influenced by other non-cancer-related conditions, and AAPR could minimize the potential basis. On the other hand, AAPR was proven to be an independent prognostic factor related with OS and DFS rather than ALB and ALP in multivariate survival analysis. As an integrated indicator, AAPR would be more reliable and might enhance its prognostic value and reflect nutritional status and immune response of patients, as well as the severity and progression of disease in a more effective way. A 0.68 cut-off value for AAPR was applied to divide patients into two groups. According to the chi-square test, the pretreatment AAPR was significantly related with age, menopause, and depth of invasion. Deep stromal invasion is considered to be an intermediate-risk factor in the management of cervical cancer. Preoperative indices in predicting the depth of invasion may benefit patients in treatment selection, especially for earlystage cervical cancer. Patients with AAPR under 0.68 were more likely to have a poor prognosis with the possibility of impaired immune-nutritional status, inadequate response to the surgical stress and increased susceptibility to infection, 
Table 2 Univariate And Multivariate Analyses Of Survival In Cervical Cancer Patients

\begin{tabular}{|c|c|c|c|c|c|c|c|c|}
\hline \multirow[t]{3}{*}{ Variables } & \multicolumn{4}{|l|}{ Overall Survival } & \multicolumn{4}{|c|}{ Disease-Free Survival } \\
\hline & \multicolumn{2}{|c|}{ Univariate Analysis ${ }^{\mathbf{a}}$} & \multicolumn{2}{|c|}{ Multivariate Analysis ${ }^{\mathbf{b}}$} & \multicolumn{2}{|l|}{ Univariate Analysis $^{\mathbf{a}}$} & \multicolumn{2}{|c|}{ Multivariate Analysis ${ }^{\mathbf{b}}$} \\
\hline & $\mathrm{HR}(95 \% \mathrm{Cl})$ & P-value & $\mathrm{HR}(95 \% \mathrm{Cl})$ & P-value & $\operatorname{HR}(95 \% \mathrm{Cl})$ & P-value & $\mathrm{HR}(95 \% \mathrm{Cl})$ & P-value \\
\hline $\begin{array}{l}\text { Age } \\
\leq 55 \text { years } \\
>55 \text { years }\end{array}$ & $\begin{array}{l}\text { I } \\
1.776(0.894-3.526)\end{array}$ & 0.101 & & & $\begin{array}{l}1 \\
1.935(1.010-3.706)\end{array}$ & $0.047^{*}$ & & \\
\hline $\begin{array}{l}\text { menopause } \\
\text { No } \\
\text { Yes }\end{array}$ & $\begin{array}{l}\text { I } \\
2.011(0.965-4.188)\end{array}$ & 0.062 & & & $\begin{array}{l}1 \\
2.078(1.037-4.161)\end{array}$ & $0.039 *$ & & \\
\hline $\begin{array}{l}\text { FIGO stage } \\
\text { IB } \\
\text { IIA }\end{array}$ & $\begin{array}{l}\text { I } \\
3.607(1.766-7.368)\end{array}$ & $<0.001 *$ & $\begin{array}{l}\text { I } \\
3.488(1.681-7.239)\end{array}$ & $0.001 *$ & $\begin{array}{l}\text { I } \\
2.922(1.459-5.853)\end{array}$ & $0.002 *$ & $\begin{array}{l}\text { I } \\
2.628(1.294-5.338)\end{array}$ & $0.008^{*}$ \\
\hline $\begin{array}{l}\text { Pathological type } \\
\text { SCC } \\
\text { No-SCC }\end{array}$ & $\begin{array}{l}\text { I } \\
2.420(1.158-5.056)\end{array}$ & $0.019 *$ & $\begin{array}{l}\text { I } \\
2.934(1.340-6.420)\end{array}$ & $0.007^{*}$ & $\begin{array}{l}1 \\
2.250(1.122-4.516)\end{array}$ & $0.022^{*}$ & $\begin{array}{l}\text { I } \\
2.644(1.280-5.462)\end{array}$ & $0.009 *$ \\
\hline $\begin{array}{l}\text { Tumor Size } \\
\leq 2 \mathrm{~cm} \\
>2 \mathrm{~cm}\end{array}$ & $\begin{array}{l}\text { I } \\
1.112(0.572-2.160)\end{array}$ & 0.755 & & & $\begin{array}{l}\text { I } \\
\text { I.153(0.619-2.147) }\end{array}$ & 0.653 & & \\
\hline $\begin{array}{l}\text { Histologic grade } \\
\text { I-II } \\
\text { III }\end{array}$ & $\begin{array}{l}\text { I } \\
0.989(0.509-1.923)\end{array}$ & 0.974 & & & $\begin{array}{l}\text { I } \\
1.090(0.586-2.027)\end{array}$ & 0.786 & & \\
\hline $\begin{array}{l}\text { Depth of invasion } \\
<2 / 3 \\
\geq 2 / 3\end{array}$ & $\begin{array}{l}\text { I } \\
2.500(1.278-4.890)\end{array}$ & $0.007^{*}$ & & & $\begin{array}{l}\text { I } \\
1.944(1.024-3.692)\end{array}$ & $0.042^{*}$ & & \\
\hline $\begin{array}{l}\text { LVSI } \\
\text { No } \\
\text { Yes }\end{array}$ & $\begin{array}{l}\text { I } \\
1.423(0.591-3.429)\end{array}$ & 0.432 & & & $\begin{array}{l}\text { I } \\
1.443(0.638-3.263)\end{array}$ & 0.379 & & \\
\hline $\begin{array}{l}\text { LNM } \\
\text { No } \\
\text { Yes }\end{array}$ & $\begin{array}{l}\text { I } \\
2.366(1.105-5.067)\end{array}$ & $0.027^{*}$ & & & $\begin{array}{l}\text { I } \\
1.958(0.930-4.123)\end{array}$ & 0.077 & & \\
\hline $\begin{array}{l}\text { Vaginal invasion } \\
\text { No } \\
\text { Yes }\end{array}$ & $\begin{array}{l}\text { I } \\
2.724(0.957-7.754)\end{array}$ & 0.060 & & & $\begin{array}{l}\text { I } \\
2.424(0.860-6.830)\end{array}$ & 0.094 & & \\
\hline $\begin{array}{l}\text { Adjuvant therapy } \\
\text { No } \\
\text { Chemoradiotherapy } \\
\text { Chemotherapy } \\
\text { Radiotherapy }\end{array}$ & $\begin{array}{l}\text { I } \\
\text { I.753(0.807-3.807) } \\
0.382(0.136-1.072) \\
8.744(2.834-26.981)\end{array}$ & $<0.001^{*}$ & $\begin{array}{l}\text { I } \\
1.651(0.739-3.688) \\
0.304(0.105-0.879) \\
5.637(1.724-18.434)\end{array}$ & $<0.001 *$ & $\begin{array}{l}\text { I } \\
1.606(0.751-3.433) \\
0.644(0.279-1.489) \\
8.413(2.739-25.838)\end{array}$ & $<0.001 *$ & $\begin{array}{l}\text { I } \\
1.507(0.690-3.291) \\
0.539(0.228-1.275) \\
6.123(1.912-19.610)\end{array}$ & $0.003 *$ \\
\hline $\begin{array}{l}\operatorname{ALB}(g / L) \\
<45.5 \\
\geq 45.5\end{array}$ & $\begin{array}{l}\text { I } \\
0.479(0.246-0.933)\end{array}$ & $0.030 *$ & & & $\begin{array}{l}\text { I } \\
0.585(0.314-1.089)\end{array}$ & 0.091 & & \\
\hline $\begin{array}{l}\operatorname{ALP}(\mathrm{U} / \mathrm{L}) \\
<73.5 \\
\geq 73.5\end{array}$ & $\begin{array}{l}\text { I } \\
2.543(1.2|8-5.3| 2)\end{array}$ & $0.013^{*}$ & & & $\begin{array}{l}\text { I } \\
2.114(1.088-4.106)\end{array}$ & $0.027^{*}$ & & \\
\hline $\begin{array}{l}\text { AAPR } \\
<0.68 \\
\geq 0.68\end{array}$ & $\begin{array}{l}\text { I } \\
0.337(0.139-0.813)\end{array}$ & $0.016 *$ & $\begin{array}{l}\text { I } \\
0.331(0.135-0.809)\end{array}$ & $0.015^{*}$ & $\begin{array}{l}\text { I } \\
0.402(0.185-0.873)\end{array}$ & $0.021 *$ & $\begin{array}{l}\text { I } \\
0.387(0.176-0.853)\end{array}$ & $0.019 *$ \\
\hline
\end{tabular}

Notes: anivariate Cox proportional hazards regression models; ${ }^{\text {} M u l t i v a r i a t e ~ C o x ~ p r o p o r t i o n a l ~ h a z a r d s ~ r e g r e s s i o n ~ m o d e l s ; ~}{ }^{*} \mathrm{P}<0.05$.

Abbreviations: FIGO, International Federation of Gynecology and Obstetrics; SCC, squamous cell carcinoma; LVSI, lympho-vascular space invasion; LNM, lymph node metastasis; ALB, albumin; ALP, alkaline phosphatase; AAPR, albumin/alkaline phosphatase ratio. 
A

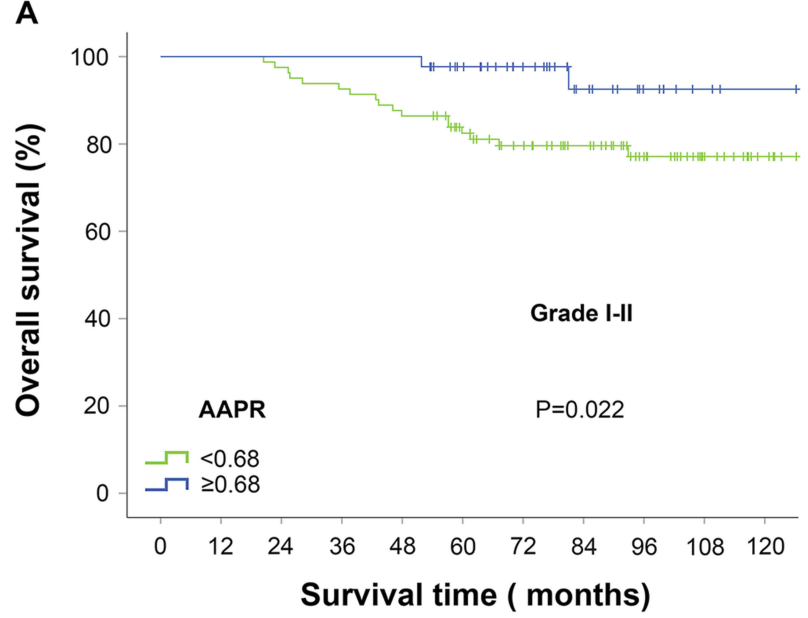

C

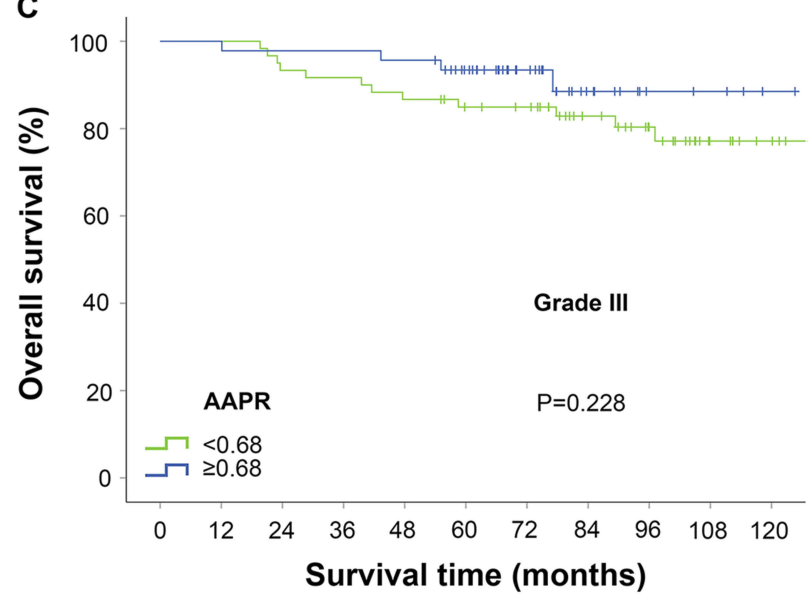

B

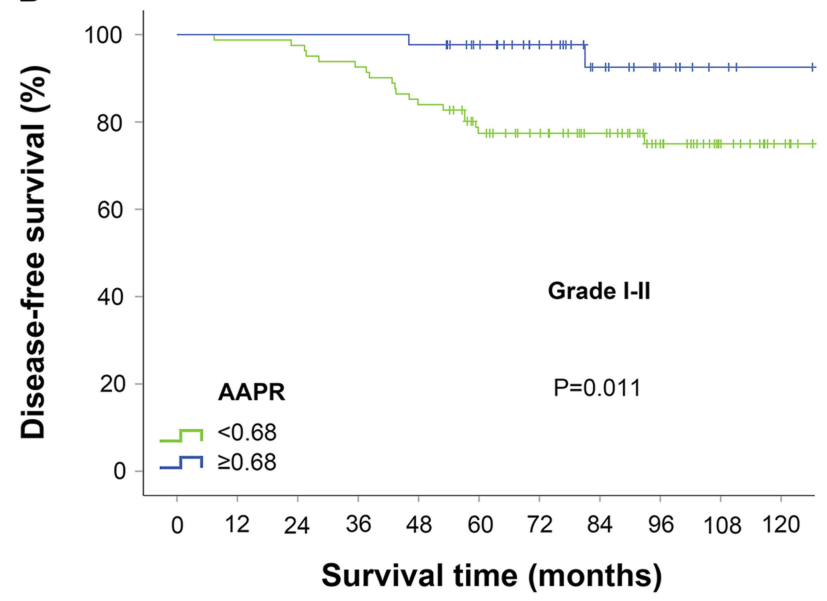

D

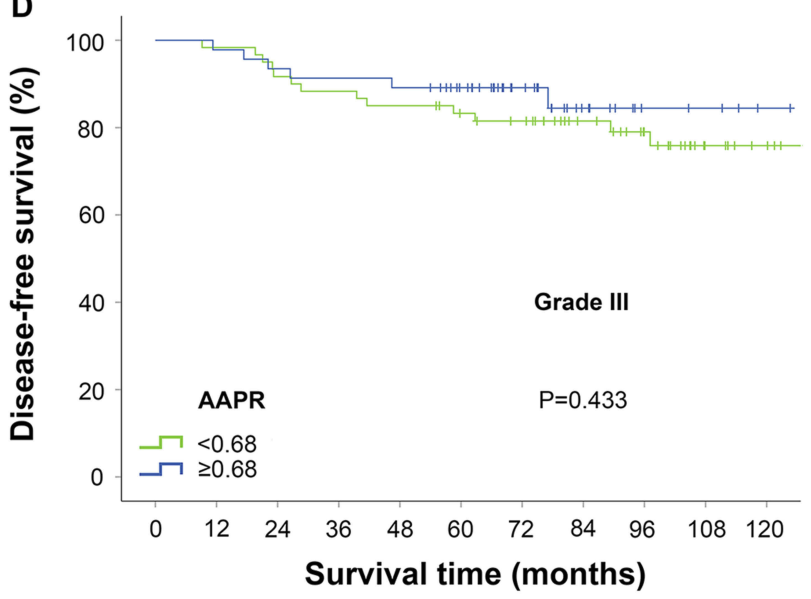

Figure 4 Kaplan-Meier curves for survival outcomes stratified according to APPR value in patients with histologic grade I-II and III. (A) Overall survival and (B) disease-free survival for patients with histologic grade I-II; (C) Overall survival and (D) disease-free survival for patients with histologic grade III. The P-values were determined by the log rank test. Abbreviation: AAPR, albumin/alkaline phosphatase ratio.

indicating the demands for increased nutritional intake, favourable anti-inflammatory therapy and improved systematic immunity. What's more, receiving immunotherapy according to clinical guidance is likely to provide a good therapeutic response in these patients. Besides, we explored the role of AAPR in subgroups with different histologic grades. Our results showed that the low AAPR contributed to worse survival outcomes in well and moderate differentiated cervical cancer; but in terms of poorly differentiated disease, there was no significant relationship between them, which was consistent with the result obtained in upper tract urothelial carcinoma. ${ }^{39}$ The result gave us a prompt that patients with low AAPR level should have their cancer status and physical condition evaluated more carefully compared with the high-AAPR group, especially in well and moderate differentiated patients.

In our study, adjuvant therapy was found to be an independent prognostic index for OS and DFS. Although various guidelines recommend radiation therapy or concurrent chemoradiation therapy as the standard adjuvant therapy to reduce recurrence in patients with high or intermediate risk factors after radical hysterectomy, adjuvant therapies remain controversial. ${ }^{42}$ Adjuvant chemotherapy alone may potentially reduce adverse events with the same efficacy as RT. ${ }^{43}$ In our study, adjuvant chemotherapy was considered according to different pathological risk factors.

There were some limitations in this study. First, this was a retrospective study conducted in a single centre with a relatively small sample size, which may have caused selection bias though both inclusion and exclusion criteria were strictly performed. Second, only stage IB-IIA cervical cancer patients who received surgery were included. Patients in different FIGO stages are needed to discuss in the future regardless of treatment options. Third, the cut-off AAPR value obtained from ROC curves might not have been optimal in other independent cohorts, and external validation is 
still needed. The underlying mechanisms of the correlation between AAPR and prognosis remain unknown, and further basic research are needed.

In conclusion, the preoperative AAPR is a novel derived indicator in stage IB-IIA cervical cancer patients with radical surgery. A low AAPR level was independently associated with inferior OS and DFS. However, larger scale, multicentre, and prospective studies are required to confirm the prognostic role of AAPR.

\section{Acknowledgments}

This research received supports from the Clinical Medicine Special Project of Nantong University (2019LQ015), Special Research Foundation of Health and Family Planning Commission of Nantong (QA2019027) and Six Talent Peaks Project of Jiangsu Province (2014YY027).

\section{Disclosure}

The authors report no conflicts of interest in this work.

\section{References}

1. Torre LA, Bray F, Siegel RL, Ferlay J, Lortet-Tieulent J, Jemal A. Global cancer statistics, 2012. CA Cancer J Clin. 2015;65:87-108. doi: $10.3322 /$ caac. 21262

2. Koh WJ, Abu-Rustum NR, Bean S, et al. Cervical cancer, version 3.2019, NCCN clinical practice guidelines in oncology. J Natl Compr Canc Netw. 2019;17:64-84. doi:10.6004/jncen.2019.0001

3. Bhatla N, Aoki D, Sharma DN, Sankaranarayanan R. Cancer of the cervix uteri. Int $J$ Gynaecol Obstet. 2018;143 Suppl 2:22-36. doi:10.1002/ijgo.12611

4. Ahn HK, Shin JW, Ahn HY, et al. Metabolic components and recurrence in early-stage cervical cancer. Tumour Biol. 2015;36:22012207. doi:10.1007/s13277-014-2831-y

5. Kim MK, Jo H, Kong HJ, et al. Postoperative nomogram predicting risk of recurrence after radical hysterectomy for early-stage cervical cancer. Int J Gynecol Cancer. 2010;20:1581-1586.

6. Lee KB, Kim YS, Lee JM. Oncologic outcomes of adjuvant chemotherapy alone after radical surgery for stage IB-IIA cervical cancer patients. J Gynecol Oncol. 2018;29:e5. doi:10.3802/jgo.2018.29.e5

7. Canaz E, Ozyurek ES, Erdem B, et al. Preoperatively assessable clinical and pathological risk factors for parametrial involvement in surgically treated FIGO stage IB-IIA cervical cancer. Int J Gynecol Cancer. 2017;27:1722-1728. doi:10.1097/IGC.0000000000001060

8. Zhang W, Liu K, Ye B, Liang W, Ren Y. Pretreatment C-reactive protein/albumin ratio is associated with poor survival in patients with stage IB-IIA cervical cancer. Cancer Med. 2018;7:105-113. doi:10.1002/cam4.1270

9. Dolan RD, McSorley ST, Horgan PG, Laird B, McMillan DC. The role of the systemic inflammatory response in predicting outcomes in patients with advanced inoperable cancer: systematic review and meta-analysis. Crit Rev Oncol Hematol. 2017;116:134-146. doi:10.1016/j.critrevonc.2017.06.002

10. Haraga J, Nakamura K, Omichi C, et al. Pretreatment prognostic nutritional index is a significant predictor of prognosis in patients with cervical cancer treated with concurrent chemoradiotherapy. Mol Clin Oncol. 2016;5:567-574. doi:10.3892/mco.2016.1028
11. Chan AW, Chan SL, Mo FK, et al. Albumin-to-alkaline phosphatase ratio: a novel prognostic index for hepatocellular carcinoma. Dis Markers. 2015;2015:564057. doi:10.1155/2015/105358

12. Nie M, Sun P, Chen C, et al. Albumin-to-alkaline phosphatase ratio: a novel prognostic index of overall survival in cisplatin-based chemotherapy-treated patients with metastatic nasopharyngeal carcinoma. J Cancer. 2017;8:809-815. doi:10.7150/jca.17536

13. Kim JS, Keam B, Heo DS, et al. The prognostic value of albumin-toalkaline phosphatase ratio before radical radiotherapy in patients with non-metastatic nasopharyngeal carcinoma: a propensity score matching analysis. Cancer Res Treat. 2019.

14. Pu N, Gao S, Xu Y, et al. Alkaline phosphatase-to-albumin ratio as a prognostic indicator in pancreatic ductal adenocarcinoma after curative resection. J Cancer. 2017;8:3362-3370. doi:10.7150/jca.20917

15. Long $Z Q$, Hua $X$, Zhang WW, et al. Prognostic impact of the pretreatment albumin to alkaline phosphatase ratio for nonmetastatic breast cancer patients. Cancer Manag Res. 2019;11:4809-4814. doi:10.2147/CMAR.S200759

16. Li D, Yu H, Li W. Albumin-to-alkaline phosphatase ratio at diagnosis predicts survival in patients with metastatic non-small-cell lung cancer. Onco Targets Ther. 2019;12:5241-5249. doi:10.2147/ OTT.S203321

17. Wang Y, Pang Q, Jin H, et al. Albumin-bilirubin grade as a novel predictor of survival in advanced extrahepatic cholangiocarcinoma. Gastroenterol Res Pract. 2018;2018:8902146. doi:10.1155/2018/ 8902146

18. Nojiri S, Joh T. Albumin suppresses human hepatocellular carcinoma proliferation and the cell cycle. Int J Mol Sci. 2014;15:5163-5174. doi:10.3390/ijms 15035163

19. Reebye V, Saetrom P, Mintz PJ, et al. Novel RNA oligonucleotide improves liver function and inhibits liver carcinogenesis in vivo. Hepatology. 2014;59:216-227. doi:10.1002/hep.26669

20. Garcia-Martinez R, Andreola F, Mehta G, et al. Immunomodulatory and antioxidant function of albumin stabilises the endothelium and improves survival in a rodent model of chronic liver failure. $J$ Hepatol. 2015;62:799-806. doi:10.1016/j.jhep.2014.10.031

21. Tang Y, Liu Z, Liang J, et al. Early post-operative serum albumin level predicts survival after curative nephrectomy for kidney cancer: a retrospective study. BMC Urol. 2018;18:111. doi:10.1186/s12894018-0427-3

22. Li P, Li J, Lai Y, et al. Perioperative changes of serum albumin are a predictor of postoperative pulmonary complications in lung cancer patients: a retrospective cohort study. J Thorac Dis. 2018;10:57555763. doi:10.21037/jtd.2018.09.113

23. Wang Y, Wang H, Jiang J, Cao X, Liu Q. Early decrease in postoperative serum albumin predicts severe complications in patients with colorectal cancer after curative laparoscopic surgery. World J Surg Oncol. 2018;16:192. doi:10.1186/s12957018-1493-4

24. Harris H. The human alkaline phosphatases: what we know and what we don't know. Clin Chim Acta. 1990;186:133-150. doi:10.1016/ 0009-8981(90)90031-m

25. Greene PJ, Sussman HH. Structual comparison of ectopic and normal placental alkaline phosphatase. Proc Natl Acad Sci U S A. 1973;70:2936-2940. doi:10.1073/pnas.70.10.2936

26. Chi KN, Kheoh T, Ryan CJ, et al. A prognostic index model for predicting overall survival in patients with metastatic castration-resistant prostate cancer treated with abiraterone acetate after docetaxel. Ann Oncol. 2016;27:454-460. doi:10.1093/annonc/mdv594

27. Liu X, Meng QH, Ye Y, et al. Prognostic significance of pretreatment serum levels of albumin, LDH and total bilirubin in patients with non-metastatic breast cancer. Carcinogenesis. 2015;36:243-248. doi:10.1093/carcin/bgu247

28. Zhang L, Gong Z. Clinical characteristics and prognostic factors in bone metastases from lung cancer. Med Sci Monit. 2017;23:40874094. doi: $10.12659 / \mathrm{msm} .902971$ 
29. Rader BA. Alkaline phosphatase, an unconventional immune protein. Front Immunol. 2017;8:897. doi:10.3389/fimmu.2017.00897

30. Rao SR, Snaith AE, Marino D, et al. Tumour-derived alkaline phosphatase regulates tumour growth, epithelial plasticity and disease-free survival in metastatic prostate cancer. Br J Cancer. 2017;116:227236. doi:10.1038/bjc.2016.402

31. Hung HY, Chen JS, Chien Y, et al. Preoperative alkaline phosphatase elevation was associated with poor survival in colorectal cancer patients. Int $J$ Colorectal Dis. 2017;32:1775-1778.

32. Wu YJ, Wang Y, Qin R, et al. Serum alkaline phosphatase predicts poor disease-free survival in patients receiving radical gastrectomy. Med Sci Monit. 2018;24:9073-9080. doi:10.12659/MSM.910480

33. Hemmat N, Baghi HB. Association of human papillomavirus infection and inflammation in cervical cancer. Pathog Dis. 2019. doi: $10.1093 /$ femspd/ftz048

34. Deivendran S, Marzook KH, Radhakrishna Pillai M. The role of inflammation in cervical cancer. Adv Exp Med Biol. 2014;816:377399. doi:10.1007/978-3-0348-0837-8 15

35. Ancuta E, Butureanu S, Zugun-Eloae F, et al. Potential value of in situ cellular immune response in HPV subtype 16 and 18 positive cervical cancer. Rom J Morphol Embryol. 2014;55:817-822.

36. Rodrigues CS, Lacerda MS, Chaves GV. Patient Generated Subjective Global Assessment as a prognosis tool in women with gynecologic cancer. Nutrition. 2015;31:1372-1378. doi:10.1016/j. nut.2015.06.001
37. Lamb GW, Aitchison M, Ramsey S, Housley SL, McMillan DC. Clinical utility of the Glasgow Prognostic Score in patients undergoing curative nephrectomy for renal clear cell cancer: basis of new prognostic scoring systems. Br J Cancer. 2012;106:279-283. doi:10.1038/bjc.2011.556

38. Ku JH, Kim M, Choi WS, Kwak C, Kim HH. Preoperative serum albumin as a prognostic factor in patients with upper urinary tract urothelial carcinoma. Int Braz J Urol. 2014;40:753-762. doi:10.1590/ S1677-5538.IBJU.2014.06.06

39. Tan P, Xie N, Ai J, et al. The prognostic significance of Albumin-toAlkaline Phosphatase Ratio in upper tract urothelial carcinoma. Sci Rep. 2018;8:12311. doi:10.1038/s41598-018-29833-5

40. Zheng RR, Huang M, Jin C, et al. Cervical cancer systemic inflammation score: a novel predictor of prognosis. Oncotarget. 2016;7:15230-15242. doi:10.18632/oncotarget.7378

41. Yu J, Zheng Q, Ding X, et al. Systematic re-analysis strategy of serum indices identifies alkaline phosphatase as a potential predictive factor for cervical cancer. Oncol Lett. 2019;18:2356-2365. doi:10.3892/ol.2019.10527

42. Niu C, Sun X, Zhang W, et al. NR2F6 expression correlates with pelvic lymph node metastasis and poor prognosis in early-stage cervical cancer. Int J Mol Sci. 2016;17:1694.

43. Asano H, Todo Y, Watari H. Adjuvant chemotherapy for early-stage cervical cancer. Chin J Cancer Res. 2016;28:228-234. doi:10.21147/ j.issn.1000-9604.2016.02.12

\section{Publish your work in this journal}

OncoTargets and Therapy is an international, peer-reviewed, open access journal focusing on the pathological basis of all cancers, potential targets for therapy and treatment protocols employed to improve the management of cancer patients. The journal also focuses on the impact of management programs and new therapeutic agents and protocols on patient perspectives such as quality of life, adherence and satisfaction. The manuscript management system is completely online and includes a very quick and fair peer-review system, which is all easy to use. Visit http://www.dovepress.com/ testimonials.php to read real quotes from published authors. 